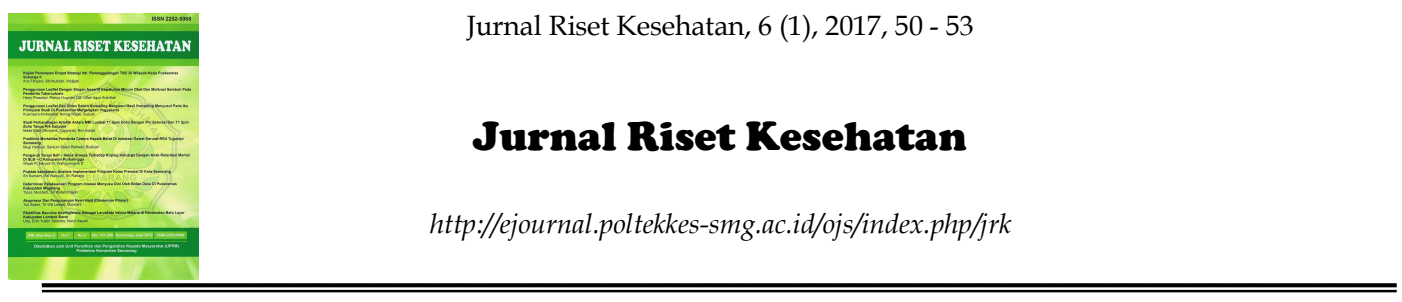

\title{
IDENTIFIKASI Neisseria gonorrhoeae PADA PENDERITA DENGAN GEJALA KLINIS INFEKSI PENYAKIT MENULAR SEKSUAL DI PUSKESMAS SIKO KOTA TERNATE TAHUN 2016
}

\author{
Erpi Nurdin*); Amira Bin Seh Abubakar ; Nurma Andi Malli \\ Jurusan Analis Kesehatan; Poltekkes Kemenkes Ternate \\ Jl. Cempaka ; Tanah Tinggi Barat ; Ternate ; Maluku Utara
}

\begin{abstract}
Abstrak
Gonorrhoeae merupakan jenis Penyakit Menular Seksual (PMS) klasik yang disebabkan oleh infeksi bakteri Neiserria gonorrhoeae. WHO memperkirakan setiap tahun terdapat 350 juta penderita baru Penyakit Menular Seksual (PMS) di Negara berkembang seperti Afrika, Asia, Asia Tenggara dan Amerika Latin. Puskesmas Siko merupakan Pusat Kesehatan Masyarakat di Kota Ternate yang dilengkapi dengan unit pemeriksaan reproduksi. Penelitian ini bersifat deskriptif observasional dan bertujuan untuk mengidentifikasi dan melihat persentase Neiserria gonorrhoeae pada penderita dengan gejala klinis Penyakit Menular Seksual. Teknik pengambilan sampel adalah secara non random dengan desain purposive sampling sebesar 40 orang. Penelitian ini menggunakan sampel swab speculum vagina. Sampel tersebut kemudian dibuat perlakuan untuk diidentifikasi dengan pengecatan gram pada apusan kering swab speculum vagina. Hasil yang diperoleh, terdapat 11 responden positif $(27,50 \%)$ teridentifikasi Neisseria gonorrhoeae dari 40 responden dengan gejala klinis infeksi menular seksual. Hasil penelitian dengan presentasi $27,50 \%$, di anggap tinggi karena melebihi Standar Nasional minimum kasus gonorrhoeae setiap wilayah 0,20\% sehingga diperlukan penanganan lebih lanjut untuk menekan tingginya angka kejadian gonorrhoeae.
\end{abstract}

Kata kunci: Neisseria gonorrhoeae ; Infeksi Menular Seksual

\begin{abstract}
[IDENTIFICATION OF Neisseria gonorrhoeae on PATIENT WITH CLINICAL SYMPTOM of SEXUALLY TRANSMITTED DISEASE AT PUSKESMAS SIKO, TERNATE CITY 2016] Gonorrhoeae is a type of sexually transmitted disease (STD) caused by the classic Neiserria bacterial infection gonorrhoeae. WHO estimates that each year there are 350 million new cases of sexually transmitted disease (STD) in developing countries such as Africa, Asia, South East Asia and America. Puskesmas Siko is a community health center in the city of Ternate is equipped with a reproductive examination. This research is descriptive observational and aims to identify and see the percentage Neiserria gonorrhoeae in patients with clinical symptoms of sexually transmitted diseases. The sampling technique is non random with quota sampling design of 40 people. This study used a sample of vaginal speculum swab. Samples are then made treatment for vaginal swab identified by the method. The results obtained, there were 11 positive respondents $(27.50 \%)$ identified Neisseria gonorrhoeae of 40 respondents with clinical symptoms of sexually transmitted infections. The results of the study with $27.50 \%$, are considered high because it exceeds the minimum National Standard of Gonorrhoeae case every Region 0,20\%. So that required further handling to suppress the high number of incidents of gonorrhoeae.
\end{abstract}

Keywords : Neisseria gonorrhoeae ; Sexually transmitted disease

\section{Pendahuluan}

Gonorrhoeae merupakan penyakit yang mempunyai insidens yang tinggi diantara Infeksi Penyakit Menular Seksual (PMS). Infeksi

*) Erpi Nurdin ini terjadi secara luas di seluruh dunia dengan

E-mail: erpinurdin88@gmail.com 
prevalensi yang lebih tinggi di berbagai negara berkembang termasuk Indonesia. (Jawas, 2008)

Puskesmas Siko sebagai salah satu pelayanan Kesehatan Reproduksi yang melakukan screening pemeriksaan dan konseling Infeksi Penyakit Menular Seksual. Data pemeriksaan melaporkan bahwa terdapat 336 pasien teridentifikasi positif terinfeksi penyakit menular seksual dari 613 pasien dengan gejala klinis. Ditemukan 30 pasien terinfeksi gonorrhoeae dari 336 pasien PMS pada tahun 2015, sedangkan Januari hingga Maret tahun 2016 di temukan 7 positif gonorrhoeae dari 36 pasien positif Infeksi penyakit menular seksual (PKM Siko, 2015; 2016).

Masa inkubasi gonorrhoeae pada wanita sulit ditentukan. Gambaran klinis dan perjalanan penyakit gonorrhoeae pada wanita berbeda dari pria, karena adanya perbedaan anatomi dan fisiologi alat kelamin pria dan wanita. Lebih dari 50\% wanita yang menderita servisitis gonorrhoeae bersifat asimtomatis. Pada umumnya wanita datang berobat kalau sudah terjadi komplikasi. Sebagian besar penderita ditemukan pada waktu pemeriksaan antenatal atau pemeriksaan Keluarga Berencana. Oleh karena itu, penapisan terhadap wanita risiko tinggi merupakan komponen yang penting untuk mengontrol gonorrhoeae (Tille, 2014).

Beberapa faktor predisposisi tingginya angka kejadian gonorrhoeae, antara lain tingkat penularan yang tinggi, masa inkubasi pendek, tingkat karier asimtomatis yang tinggi, tidak adanya imunitas protektif, meningkatnya resistensi terhadap antibiotik, dan perubahan perilaku seksual. Prevalensi servisitis gonorrhoeae di kalangan perilaku seksual risiko tinggi, yaitu penjaja seks komersial wanita (PSKW) di wilayah lokalisasi, termasuk di Kota Ternate. Penentuan diagnosis penyakit gonorrhoeae dengan pemeriksaan mikrobiologis, mencari mikroorganisme penyebab penyakit gonorrhoeae yaitu bakteri Neisseria gonorrhoeae. Keberadaan bakteri diplococcus Gram negatif intraseluler di dalam lendir endoservix menunjukkan telah terjadi infeksi patogen, karena bakteri ini bukan anggota flora normal vagina. Infeksi oleh bakteri ini menimbulkan penyakit gonorrhoeae yang terutama menyerang saluran urogenital pada laki-laki dan perempuan, dapat pula menginfeksi permukaan mukosa lainnya (mukosa konjunctiva mata, mukosa mulut, mukosa faring, mukosa rektum) dan dapat pula menyebar ke persendian (meskipun jarang).

\section{Metode}

Jenis penelitian ini adalah deskriptif observasional yang bertujuan untuk mengetahui atau mendapat gambaran kejadian dan distribusi suatu penyakit pada populasi secara objektif. Pengambilan sampel dilakukan secara non random dengan desain purposive sampling dimana sampel telah ditentukan oleh peneliti 40 sampel.

Alat dan bahan yang digunakan dalam penelitian ini yaitu mikroskop (Leica DM500), objek gelas (Slide), Cocor bebek disposible (One-Med Vagion), Tube swab specimen collection (AM-Med), $\mathrm{NaCl}$ Fisologis steril 0,9\%(merck, 99\%), Gentian Violet (STReagensia), Lugol (ST-Reagensia), Etanol 96\% (merck, 95\%), Fuchsin (ST-Reagensia), dan Minyak emersi (Agritech).

Metode kerja menggunakan teknik pewarnaan gram pada apusan kering swab speculum vagina. Spekulum vagina di ambil dengan menggunakan cocor bebek disposible.

\section{Hasil dan Pembahasan}

Data penelitian diperoleh dari pengambilan sampel berupa swab spekulum vagina yang di ambil pada klinik infeksi menular seksual di Puskesmas Siko Kota ternate. Sedangkan pemeriksaan sampel dan Pengamatan slide dilakukan di Laboratorium Terpadu Poltekkes Kemenkes Ternate.

Tabel 1. Hasil Pemeriksaan Neisseria gonorrhoeae pada sampel swab speculum vagina pada pasien dengan gejala klinis IMS

\begin{tabular}{cccc}
\hline No & Kode & $\begin{array}{c}\text { Umur } \\
\text { (tahun) }\end{array}$ & $\begin{array}{c}\text { Hasil } \\
(\text { N. gonorrhoeae })\end{array}$ \\
\hline 1 & SV1 & 36 & Positif \\
2 & SV2 & 38 & Negatif \\
3 & SV3 & 43 & Negatif \\
4 & SV4 & 42 & Negatif \\
5 & SV5 & 44 & Positif \\
6 & SV6 & 36 & Negatif \\
7 & SV7 & 54 & Negatif \\
8 & SV8 & 32 & Negatif \\
9 & SV9 & 29 & Negatif \\
10 & SV10 & 22 & Negatif \\
11 & SV11 & 29 & Negatif \\
12 & SV12 & 34 & Negatif \\
13 & SV13 & 29 & Negatif \\
14 & SV14 & 57 & Negatif \\
15 & SV15 & 47 & Negatif \\
16 & SV16 & 39 & Negatif \\
17 & SV17 & 31 & Negatif \\
18 & SV18 & 32 & Negatif \\
19 & SV19 & 36 & Negatif \\
20 & SV20 & 36 &
\end{tabular}




\begin{tabular}{llll}
21 & SV21 & 21 & Negatif \\
22 & SV22 & 38 & Negatif \\
23 & SV23 & 30 & Negatif \\
24 & SV24 & 44 & Negatif \\
25 & SV25 & 29 & Negatif \\
26 & SV26 & 54 & Positif \\
27 & SV27 & 43 & Positif \\
28 & SV28 & 33 & Positif \\
29 & SV29 & 38 & Negatif \\
30 & SV30 & 43 & Positif \\
31 & SV31 & 54 & Positif \\
32 & SV32 & 36 & Negatif \\
33 & SV33 & 39 & Negatif \\
34 & SV35 & 45 & Positif \\
35 & SV36 & 52 & Negatif \\
36 & SV37 & 44 & Negatif \\
37 & SV39 & 46 & Positif \\
38 & SV40 & 33 & Negatif \\
39 & SV41 & 42 & Positif \\
40 & SV42 & 35 & Positif \\
\hline
\end{tabular}

Dari hasil pemeriksaan sampel pada tabel 1 menunjukkan bahwa dari 40 orang responden ditemukan 11 orang responden pada swab spekulum vagina pasien dengan gejala klinis IMS, di temukan Neisseria gonorrhoeae.

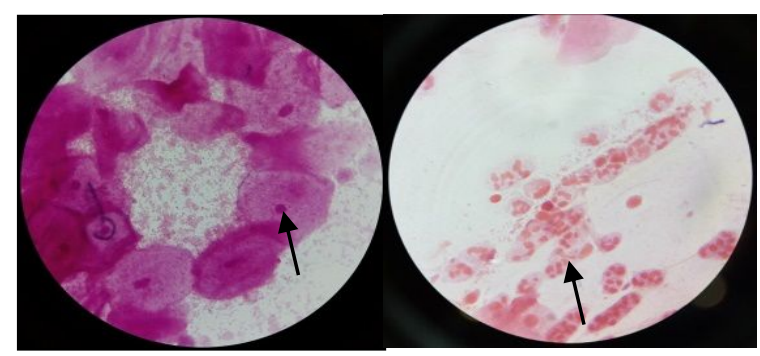

Gambar 1. Neisseria gonorrhoeae tampak sebagai diplococcus yang intraseluler (1000x)

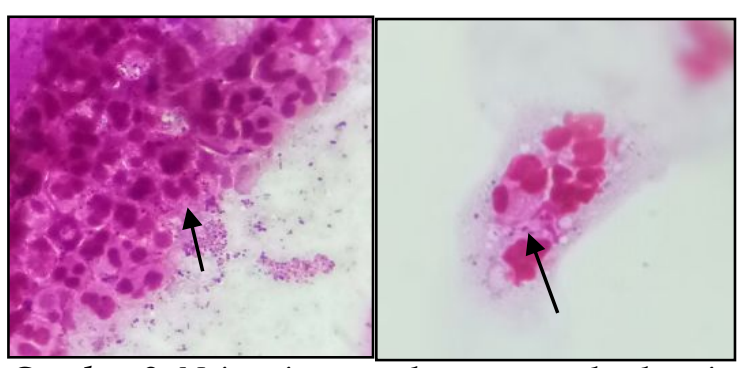

Gambar 2. Neisseria gonorrhoeae tampak sebagai diplococcus Intraseluler dan Ekstraseluler (1000x)

Tabel 2. Frekuensi Hasil Pemeriksaan Neisseria gonorrhoeae pada pasien dengan gejala klinis Infeksi Menular Seksual (IMS)

\begin{tabular}{ccc}
\hline N. gonorrhoeae & \multicolumn{2}{c}{ Jumlah } \\
\cline { 2 - 3 } Positif & $\mathrm{N}$ & $\%$ \\
Negatif & 11 & 27,50 \\
Total & 29 & 72,50 \\
& 40 & 100 \\
\hline
\end{tabular}

Tabel 2, menunjukkan bahwa 40 sampel dari swab spekulum vagina diperoleh 11 orang $(27,50 \%)$ terdapat Neisseria gonorrhoeae, dan 29 orang $(72,50 \%)$ tidak terdapat Neisseria gonorrhoeae.

Gonorrhoeae (GO) sebagai infeksi bakteri yang disebabkan oleh bakteri Neisseria gonorrhoeae, suatu diplococcus gram negatif. Infeksi umumnya terjadi pada aktivitas seksual secara genitor-genital, namun dapat juga kontak seksual secara oro-genital dan ano-genital. Pada laki-laki umumnya menyebabkan urethritis akut, sementara pada perempuan menyebabkan servisitis yang mungkin saja asimtomatik (Jawas, 2008).

Menurut data dari Komisi Nasional Anak terdapat sekitar 300.000 Pekerja Seks Komersial (PSK) wanita di seluruh indonesia, sekitar 70.000 diantaranya adalah anak dibawah usia 18 tahun. Jumlah PSK wanita yang banyak selain menimbulkan masalah sosial juga menimbulkan banyak masalah kesehatan. Masalah kesehatan yang utama terjadi pada PSK adalah penyakit menular seksual (PMS), yaitu penyakit yang penularannya terutama melalui hubungan seksual. PSK wanita dapat menjadi sumber penularan kepada masyarakat melalui laki-laki konsumennya. PMS yang umum terjadi di masyarakat adalah gonorrhoeae $(16-57,7 \%)$ dari kasus PMS), kemudian Non Gonococal uretritis (24-54\%), Candidiasis (23\%), Tricomoniasis, Syphilis, Condiloma, Genital Herpes (Purwono, 2015).

Kelompok seksual berperilaku berisiko tinggi antara lain commercial sex workers (CSWs). Berdasarkan jenis kelaminnya, CSWs digolongkan menjadi female commercial sexual workers (FCSWs) atau wanita penjaja seks (WPS) dan male commercial sexuall workers (MCSWs).

Gonorrhoeae jenis PMS klasik yang disebabkan oleh infeksi bakteri Neisseria gonorrhoeae, keberadaannya sudah diketahui sejak zaman Hipocrates, namun sampai sekarang masih menjadi masalah kesehatan yang belum dapat diatasi secara tuntas. Penyakit ini banyak ditemukan hampir di semua bagian dunia. Laporan WHO pada tahun 1999 secara global terdapat 62 juta kasus baru gonorrhoeae (Purwono, 2015).

Peluang untuk infeksi menular seksual di sebabkan oleh adanya perilaku seks yang menyimpang seperti bergantian pasangan, higiene personal, serta tidak menggunakan kondom sebagai alat yang dapat meminimalisir angka kejadian Infeksi Menular Seksual (IMS), 
khususnya infeksi bakteri Neisseria gonorrhoeae. Sulitnya pengobatan infeksi menular seksual ini, disebabkan kurangnya kesadaran dan adanya rasa takut serta malu untuk memeriksakan pasangan suami isteri yang berisiko tinggi.

Hasil positif $27,50 \%$ positif teridentifikasi Neisseria gonorrhoeae, di anggap tinggi karena memiliki efek mortalitas yang tinggi dan dapat berpotensi tinggi terjadi penularan bila tidak teratasi dengan baik. Untuk penanggulangan, diperlukan anamnesa yang tepat, dan didukung dengan pemeriksaan laboratorium yang berstandar untuk melakukan pemeriksaan pada pasien Infeksi Menular Seksual (IMS).

Infeksi menular seksual sangat berbahaya ketika tidak terdiagnosa dengan baik, sehingga diperlukan pemeriksaan fisik, pemeriksaan laboratorium, pengobatan, dan edukasi yang baik untuk menekan penyebaran IMS. Pasien yang datang memeriksakan, kebanyakan dari sex wanita. Sedangkan untuk pasangan, dalam hal ini suami memerlukan konseling yang lebih dalam untuk memutuskan melakukan pengobatan secara berkelanjutan.

Hasil penelitian dengan presentasi $27,50 \%$, di anggap tinggi karena melebihi Standar Nasional minimum setiap wilayah $0,20 \%$. Sehingga diperlukan penanganan lebih lanjut untuk menekan tingginya angka kejadian gonorrhoeae.

Pasien IMS dengan jenis kelamin laki-laki jarang di jumpai melakukan pemeriksaan IMS, ini di sebabkan laki-laki merasa baik-baik saja di stadium awal.

\section{Simpulan dan Saran}

Berdasarkan penelitian yang telah dilaksanakan, maka diperoleh kesimpulan bahwa pada sampel responden di temukan Neisseria gonorrhoeae, dan terdapat 11 responden (27.50\%) positif ditemukan diplococcus Neisseria gonorrhoeae dari 40 sampel swab spekulum vagina yang diperiksa.

Berdasarkan kesimpulan dari penelitian ini, maka perlu disarankan melakukan penelitian lanjutan pada tahap kultur dan molekuler pada swab spekulum vagina penderita Infeksi Menular Seksual, serta Kepada Dinas Kesehatan Kota Ternate dan Puskesmas Siko untuk melakukan pemeriksaan berkelanjutan, melakukan tahap pengobatan, dan konseling tentang pencegahan Infeksi Menular Seksual.

\section{Ucapan Terima Kasih}

Terimakasih disampaikan kepada Poltekkes Kemenkes Ternate yang telah mendanai keberlangsungan jurnal ini, pihak Puskesmas Siko Kota Ternate yang telah mendukung dalam tahap sampling dan konseling untuk pasien yang terdiagnosa terinfeksi gonorrhoeae, serta tim peneliti dan enumerator yang telah mendukung seluruh tahapan penelitian.

\section{Daftar Pustaka}

Bignell, et al. (2011). UK nasional guideline for the management of gonorrhoeae in adults.

Brooks, et al. (2013). Manual Medical Microbiology. The McGraw-Hill, lange.

Fitri Abdullah Jawas, dkk. (2008). Penderita Gonore di Divisi Penyakit Menular Seksual Unit Rawat Jalan Ilmu Kesehatan Kulit dan Kelamin RSU Dr. Soetomo.Download-fullpaperBKKK_vol20no3_des_2008-Acc_4.pdf.

Mahon, CR, Lehman. (2015). Textbook of Diagnostic Microbiology. $5^{\text {th }}$ edition, Saunders Elsevier Mosby-Missouri.

Priyo Budi Purwono, dkk. (2015). Pemeriksaan mikrobiologi untuk penyakit infeksibakteriologi infeksi genitalia, Fakultas Kedokteran Universitas Airlangga, Sagung Seto. Surabaya.

Oslen, et al. (2013). Antimicrobial susceptibility and genetic caharacteristics of Neisseria gonorrhoeae isolates from Vietnam, 2011, http:// www.biomedcentral.com/14712334/13/40.pdf.

Public Health England (PHE). (2015). Identification of Neisseria species, England.

Puskesmas Siko. (2016). Profil Puskesmas Siko. Ternate ; Maluku Utara.

Somsel, et al. (2007). Culture and Smear for the isolation and identification of Neisseria gonorrhoeae ; Infectios Disease Journal, di akses 21 April 2016, http://www.biomedcentral.com/14712355/13/40.pdf.

Tille, PM (editor). (2014). Bailey and Scott's Diagnostic Microbiology, $13^{\text {th }}$ edition". Elsevier Mosby-Missouri.

WHO. (2008). Global incidence and prevalence of selected curable sexually transmitted infection,http://www.who.int./reproduc tivehealth/publication/rtis/2008_STI_est imates.pdf. 